Peer-Reviewed Article

ISSN: 2162-3104 Print/ ISSN: 2166-3750 Online

Volume 7, Issue 3 (2017), pp. 467-485

(C) Journal of International Students

http://jistudents.org/

\title{
International Students' Views on Local Culture: Turkish Experience
}

\author{
Yakup Çetin \\ Ishik University, Iraq \\ Mustafa Bahar \\ International Burch University, Bosnia Herzegovina \\ Carol Griffiths \\ MEF University, Turkey
}

\begin{abstract}
The number of international students in Turkey has steadily increased in recent years. As they come from different geographical locations, their successful adaptation to a medium sized country in-between three continents is of great interest. This study was conducted to investigate international students' perceptions of their Turkish experience. After an interview with 9 international students, a 46-item questionnaire was developed and given to 421 students; of these, 319 students from 61 countries returned complete forms. Responses were generally positive, although some difficulties according to gender, religion or age were reported. Another 12 students' written comments were compared with quantitative data. Implications are suggested as well as directions for further research.
\end{abstract}

Keywords: Turkish culture, international students, perception, gender, religion, nationality

International mobility has had an important influence on students and institutions all over the world (Russell, Rosenthal \& Thomson, 2010) and the number of students who pursue their academic education in a different country has grown to over 3 million over the last decade (Rienties, Beausaert, Grohnert, Niemantsverdriet \& Kommers, 2011). Until recently, countries where the target language is spoken as the native language attracted most international students (e.g. UK or USA for those who wanted to learn English). However, countries such as Turkey are now attracting more and more international students. 


\section{LITERATURE REVIEW}

There are several reasons why students go abroad for international academic programs. These include the opportunity to experience another culture and its educational system, to make new friendships, to develop cultural competence skills, to improve self-esteem and confidence, and to broaden horizons (Andrade, 2006; McClure, 2007; Sherry, Thomas \& Chui, 2009) and academic quality. Those host countries and institutions that are not able to meet the expectations of international students may cause feelings of regret, anger, shock, and confusion (Sherry, Thomas \& Chui, 2009). According to the findings of a number of studies, many international students are subject to language and cultural barriers, academic difficulties, economic problems, racial discrimination, homesickness, culture shock, indecision, and even physical illness (Biggs, 1999; Brown, 2007; Furnham, 1997; Yeh \& Inose, 2003). As an example, a recent study by Russell, Rosenthal, and Thomson, (2010) revealed that 41percent out of 900 international students in Australia experienced high levels of stress, usually as a result of homesickness, culture shock, or perceived discrimination. Altbach and Teichler (2001) considered the international students a vulnerable population who are open to exploitation in the form of low quality education, financial abuse, and negligence. In the following paragraphs, we will examine some of the most common problems international students encounter in their new setting.

The Higher Education Council (YÖK) in Turkey defines international students as anyone without Turkish citizenship, getting education at any level and area or taking Turkish language courses (Resmi Gazete, 1985). International students come to Turkey from many different origins, including the Far East (such as Japan, Korea or China), South-east Asia (such as Vietnam, Thailand or Cambodia), Central Asia (such as Azerbaijan, Kazakhstan or Kyrgyzstan) the Middle East (such as Iran, Iraq or Saudi Arabia), the Indian sub-continent (such as India, Bangladesh or Pakistan), Africa (such as Kenya, Uganda or Nigeria), Europe (such as Germany, Russia or Spain), Scandinavia (such as Finland, Norway or Sweden) or Latin America (such as Brazil, Colombia or Chile). While most of these are non-English speaking, there are also some students who come from English speaking backgrounds, such as USA, UK, Oceania or South Africa. Since Turkey is a predominantly Muslim country, a majority of the international students tend to be Muslim, but other faiths (such as Buddhism or Christianity) are also represented, and Islamic dress codes are not imposed. International students can be of either gender, and although a majority would be in their $20 \mathrm{~s}$, a wide range of age groups (15 to 60 in the current study) are represented. Although a majority of these students would have scholarships to study in Turkey (either from Turkey or from their own 
governments), others are full fee-paying students, and most of them would be studying in universities where English is the medium of instruction.

\section{Language and education factors}

Among the factors that influence student success is language proficiency. According to Andrade (2006), language proficiency plays a key role in the success of international students in relation to academic and social adjustment. Yeh and Inose (2003) also pointed out that language competence is the most obvious barrier that international students face, since it is vital for academic and social interactions. For instance, based on a survey, Probertson, Line, Jones and Thomas (2000) found that academic staff were not empathetic towards international students with low language proficiency and criticized them for not being serious about their academic development. The findings of another study indicate that international students often pretended to understand conversations exchanged with their instructors when they did not because of limited language ability (Terui, 2012). As a result of this, instructors often question international students' ability to meet course requirements, expect them to take remedial classes, or criticize their accents. According to a study at the University of Toledo, international students expressed lack of oral communications skills as being more challenging than written language problems (Sherry et al., 2009). This may be because problems with language are experienced on a daily basis and may prevent communication with faculty administration, staff, peers, and the community. Nevertheless, a study by Fass-Holmes and Vaughn (2015) found that international students can be successful in their studies in spite of struggling with the language

Differences in educational systems may also be a barrier for international students, as described by Palmer (2015), who wrote of feeling like an outsider on the "not-so-easy road of overseas study" (p.541). In some countries, education is mainly based on material success, competition, excellence, ambition, and achievement. Other countries promote moderate, sympathetic, and cooperative values, excellence is played down, and failure is simply a stepping-stone to success (Hart, 2012). Students coming from learner-centered education systems may encounter great problems in adapting to a teacher-centered education system, and vice versa. Furthermore, because of religious sensitivity in some cultures, participation of male and female students in the same class setting might be avoided (Carr, Koyama \& Thiagarajan, 2003).

\section{Personal factors}

International students may feel lonely in their new home. Lack of immediate friends, social networks, and cultural or linguistic familiarity are among the main reasons for loneliness (Sawir, Marginson, Deumert, Nyland 
\& Ramia, 2008). In addition, homesickness may lead to depression and anxiety (Mesidor \& Sly, 2016). Both social support and social connectedness by family and new friends contribute greatly to the success of international students in their new environment (Sam, 2001; Wilcox, Winn \& Fyvie-Gauld, 2005). As an example, Severiens and Wolff (2008) reported that those international students who felt at home and were well connected to the host institution (including the faculty staff and students) and who participated in extra-curricular activities were more likely to enjoy academic and social success. Also, Glass (2012) found that International students who took part in cooperative and group-oriented programs within the university and local community tended to report more positive views about cultural diversity as well as personal and social development. It has been found that international students who have a number of friends from the same country as well as the host country, who share accommodation with other students, and who take part in different student organizations are more socially integrated and do better academically (Russell et al., 2010). A compilation of findings from other studies also shows a positive correlation between cocurricular activities and successful integration of international students into the academic and local community (Saenz, Ngai \& Hurtado, 2007; Trice, 2004). Therefore, we can conclude that a friendly and supportive institution and community plays an important role in the psychological well-being of international students (Sümer, Poyrazli \& Grahame, 2008).

Previous research suggests that financial pressure is another important problem international students may face which may result in poor academic performance (e.g. Thomas, 2002). Lack of financial resources, low family income, inability to find part-time employment, and the cost of extra tuition are listed as financial barriers. Particularly, international students who do not receive financial aid have to cover tuition and living costs all by themselves. It is known that the fee international students have to pay to the host university is often quite high, compared to local students. According to Singh (2008), most international students are from developing countries with much lower GDPs, that is why financial problems are unavoidable. Sherry et al. (2009) suggested that the socioeconomic conditions of the family might be a possible barrier for success during international study. Rienties et al., (2011) found that non-western students received less financial support from family and friends than western students. Similarly, Meeuwisse, Severiens and Born (2010) indicated a strong relationship between drop-outs among international students and low socio-economic background.

The negative impact of discrimination and racial prejudice on international students have been well-documented (e.g. Gareis, 2012; Hanassab, 2006; Lee and Rice, 2007; Locks, Hurtado, Bowman \& Oseguera, 2008; Yoon \& Portman, 2004). International students who are 
directly or indirectly exposed to discrimination (such as race, color, belief, gender, and identity) including verbal insults feel more depressed and stressed (Jung, Hecht \& Wadsworth, 2007). Sherry et al. (2009) argue that it is not fair to put all the responsibility for change, adaptation and adjustment on the international students. The literature suggests ways in which the host institution and culture can be more (or less) helpful to international students in dealing with issues such as discrimination. A number of studies emphasize the role of social support networks promoted by the host institution or country in alleviating the effects of discrimination (Noh \& Kaspar, 2003; Poyrazli, Kavanaugh, Baker \& Al-Timimi, 2004).

As they live in the host country for a quite long period of time, international students may tend to stay there after their studies are complete to take advantage of employment opportunities (Baruch, Budhwar \& Khatri, 2007). A reason for this is that they may consider that work experience abroad may provide more job opportunities after returning to their home country (Dustmann \& Weiss, 2007). That is to say, work experience in a different country, particularly in a developed country, can be viewed as competence and prestige in the home country that may attract employers back home. However, it is not always easy for many international students to find a suitable job in the host country upon completing their education.

\section{Cultural factors}

According to Zhou and Griffiths (2011), culture can be regarded as any of the practices which distinguish one group of people from others. Culture at surface level can be defined as everything that makes up a person's entire way of life such as food, clothes, music, entertainment, and so on. Culture at a deeper level consists of customs and traditions, perceptions, beliefs, values, and attitudes (Byram, 1989). It is widely accepted that people use culture to interpret experience and behavior: it is the "software of the mind", as Hofstede (1997, p.1) famously put it. According to Spindler (1987), people from the same cultural background tend to share similar beliefs, values and attitudes which they pass on from generation to generation. This cultural transmission - a set of socially shared values and behaviors - usually takes place in the family, school, workplace, community, and media (Scollon \& Scollon, 1995). Miscommunication and misunderstanding may be more likely to happen between people who are members of different cultures, owing to social distance (Schumann, 1975, 1976).

In line with this, the first experience in the new culture might be very challenging for those international students who have never travelled abroad before. Even those students who already have had experience with other cultures still need adjustment when visiting or studying in a new culture (e.g. Yeh \& Inose, 2003). It is likely that there can be 
misunderstandings between international students and those from the local culture during interactions when there is lack of cross-cultural awareness. As an example, because of lack of intercultural awareness, students may easily experience culture shock (Oberg, 1960) when they fail to adapt their attitudes and behaviors in order to fit into quite different social contexts. Accordingly, people who are subject to culture shock may experience feelings of self-pity and anger and complain that others do not understand them, which may result in negative feelings towards the new culture (Brown, 2007).

Archer's (1986) term "culture bump" refers to situations where people from different cultural backgrounds experience states of discomfort and strangeness during their interaction. According to Archer, a culture bump happens when a person's expected behavior is perceived differently by people from other cultures. Thus, cultural preconceptions directly or indirectly influence the interpretation of attitudes and behaviors on social, cultural and personal levels. Culture bumps can be caused by communication styles, understanding of time, physical appearance, or even artifacts and architecture. As an example, people from different cultures may want to greet each other; however, they may experience feelings of distress and anxiety due to proxemics and formality differences. When being greeted, average American males would greet back and perhaps shake hands depending on the relationship, whereas Turkish males would go one step further either by hugging or knocking their heads together to show their approval and solidarity if they are very close friends. Actually, both males from completely different cultures may be trying to be sincere in greeting, but their physical response might be misunderstood by the other person who has different expectations about behavior.

Turkish women tend to hug each other when they meet, and since this is regarded as "normal" in their culture, they may find British people, who tend to be more reserved, "cold". Therefore, international students who would like to study abroad have to take cultural differences like 'culture bump' into consideration since they are inevitable across cultures. Byram and Feng (2005) and Bateman (2002) argue that integrating cultural awareness into the curriculum can help to overcome negative experiences like culture shock and culture bumps and develop positive attitudes towards other cultures.

International students may contribute to the cultural diversity of the host country and institution with their home culture and ethnic experiences including, beliefs, traditions, language, food, clothing, music, and so on. That is to say, they may help the local community to develop their cultural awareness and worldview by interacting with people from different backgrounds (Hammer, Bennett \& Wiseman, 2003). Even though all these are assets that international students may offer, many of them are still 
subject to prejudice. For example, a study which aimed to investigate attitudes toward international students found that American students considered international students as a threat to their liberty, education, beliefs, values, physical wellbeing, and social life (Charles-Toussaint \& Crowson, 2010). Therefore, lack of intercultural communication and cultural awareness may result in anxiety about interacting with people from different backgrounds. It is possible that if the local community has anxiety about contact with foreigners, it may create a negative stereotype about international students who may have a different culture, history, belief system, identity, language and gender definition. As an example, Hitlan, Carillo, Zárate and Aikman (2007) demonstrated that since September 11 there has been a greater perception of threat against Mexican and Arab immigrants in the US.

In line with global trends, the number of international students in Turkey has been steadily growing in recent years (Özer, 2012). Soon after their arrival, naturally international students start exploring the Turkish language in order to cope with the new environment. Many of them take Turkish language courses either from their host universities or TÖMER (Turkish and Foreign Languages Research and Application Center) in order to be able to pursue their studies and function well in Turkish society, including everyday matters such as using public transport or going shopping.

\section{RESEARCH METHOD}

The research questions for this study were: How do international students view their experience in Turkey? Do these views vary according to age? Do these views vary according to gender? Do these views vary according to beliefs? Do these views vary according to nationality? This study used a mixed methods approach, including interviews, a questionnaire, and written reflections. It was hoped that by combining quantitative and qualitative research methods it would be possible to obtain more in-depth insights into the students' views of their experience in Turkey than would be possible using just one method on its own.

\section{Participants and setting}

Initially, nine students from different continents (one from South America, three from Europe, three from Asia, two from Africa) wrote down about their experiences in Turkey, which formed the bases for a questionnaire and then a total of 421 international students studying at various state and private Turkish language courses filled in the questionnaire. Since some of the forms did not have all ratings or all details regarding age or gender, they were not included in the analysis, leaving a 
total of 319 complete forms. Ages ranged from 15 to 60, and 309 participants indicated their gender (185 males and 124 females). The majority $(\mathrm{N}=247)$ gave their religion as Islam, while the others $(\mathrm{N}=72)$ gave a variety of answers to this question (including Christian, Orthodox, Buddhist, atheist, or some chose not to answer this item, which was optional). The students came from 61 different countries, including countries in Europe, the Middle East, Asia, Africa, North and South America, and Oceania, while 7 did not give their country of origin.

\section{Data collection}

The study consisted of three stages. As a first stage of the study, we interviewed 9 international students from different countries of the world about what problems they faced, what experiences they had, what they liked and disliked most while studying in Turkey. Their perceptions and experiences along with data from cultural studies in the field formed the basis for the present questionnaire which consisted of 46 items. A Likertscale item format was used which, in addition to biographical information (age, gender, religion, country of origin), asked the students to rate the statements on a scale of 1 to 5 where $1=$ strongly disagree and $5=$ strongly agree. We applied the questionnaire to students in various courses in a metropolitan city. As the third stage, 12 interviewees submitted written reflections which were analyzed qualitatively for additional insights regarding the questionnaires.

\section{Data Analysis}

First we coded and categorized written responses of the students and after forming and applying the questionnaires, we entered the data onto SPSS and calculated Cronbach's alpha test for reliability. Since Likert scales are non-numerical in nature, we used non-parametric tests (medians, Spearman's rho for correlation and Mann-Whitney U for differences) to analyze the data. Several items (numbers 1, 2, 14 and 29), which were worded negatively in the original, were reversed during the analysis process. We used the grounded approach for the qualitative data provided by the interviewee reflections, employing a succession of coding steps (open, axial and selective).

\section{Reliability}

\section{FINDINGS AND DISCUSSION}

When analyzed for reliability, the 46 items returned an alpha coefficient of .864, which is considered a reasonably strong result (De Vaus, 1995). In other words, this questionnaire can be considered a reliable instrument for measuring the target construct (international students' views about their Turkish experience). For the qualitative data, inter-rater 
reliability was calculated to be 94 percent and differing opinions in the coding were resolved by consultation with an independent colleague.

\section{Levels of agreement}

As can be seen from Appendix 3, the majority of the items in the questionnaire, that is 33 of the 46 items ( 71.7 percent), received a median rating of 4 , indicating that the respondents $(\mathrm{N}=319)$ are generally in agreement with the statement. These positively rated statements include several which suggest that the respondent feels comfortable in Turkey, e,g,:

I feel comfortable with Turkish culture

Turkish people are friendly to foreigners

I feel comfortable among Turkish people

Turkish people are hospitable

Turkish society is open to other cultures

Although there are some items which seem to indicate an awareness of difference, there does not appear to be any suggestion that this is problematic:

The relationship between boys and girls is different

I find Turkish architecture different

\section{Age differences}

There were several items where younger and older respondents, who ranged in age from 15 to 60 , with a mean of 21.98 , varied significantly in their points of view. Older people, for instance, are significantly more in agreement about the importance of family $(r=.168, p<.01)$ and religion $(r=.148, p<.05)$ than younger people. They also appear to be significantly more in favour of the way Turkish people greet each other $(r=.156, p<.01)$, to appreciate Turkish arts and crafts $(r=.205, p<.01)$, and the antiquity of the civilization $(r=.225, p<.01)$. By contrast, younger people are more likely to agree that there is discrimination between people in Turkey $(r=-.118$, $p<.05)$

\section{Gender differences}

Women $(\mathrm{N}=124)$ are significantly more likely than men $(\mathrm{N}=185)$ to think that Turkish people are talkative $(U=15.871, p<.05)$, to like traditional Turkish dances $(U=15.947, p<.05)$, and to find Turkish people nationalistic $(U=15.441, p<.01)$. Men, on the other hand, are significantly more likely to believe that there is religious freedom in Turkey $(U=10.790, p<.01)$. Compared with women, men are significantly more in agreement that Turkish is a popular language $(U=11.525, p<.01)$, that Turkey is a tea drinking nation $(U=10.253, p<.01)$ and that Turkish culture can be a model $(U=11.801, p<.01)$. Men are also significantly more inclined to like Turkish 
family relationships $(U=12.274, p<.05)$, to believe their people and Turkish people can live together $(U=11.701, p<.05)$ and to believe that Turkish teaching styles are similar to those in their own countries $(U=11.914$, $p<.05)$.

\section{Religion}

Since the major religion in Turkey is Islam, we might expect that even among international students, the majority would be Muslim, since they would probably feel more comfortable choosing an environment with a similar faith to their own. The figures show that this is, indeed, the case, with 247 declaring themselves to be Muslim, and the remaining 72 either not answering the question (which was optional) or nominating a number of other religions, including Christian, Orthodox, Buddhist and atheist. Those who say they are Muslim are significantly more likely than nonMuslims to find Turkish an easy language to learn $(U=4.778, p<.05)$ and to believe that there is freedom $(U=4.348, p<.01)$, particularly religious freedom $(U=3.396, p<.01)$ in Turkey. Muslims are also significantly more likely to believe that Turkish people have good manners $(U=4.528, p<.05)$ and that Turkey looks like a European country $(U=4.652, p<.05)$. Besides, Muslim learners are more likely to believe that Turkish people are open to other cultures $(U=4.629, p<05)$, that their people and Turkish people can live together and that Turkish people are tolerant to other religions $(U=4.280, p<.01)$, that Turkish food is similar to the food in their country $(U=4.443, p<.05)$. Non-Muslims, on the other hand, although they agree that religion plays a significant role in Turkey $(U=8.030, p<.01)$, tend to focus more on the importance of family $(U=7.115, p<.05)$ and other features of Turkish life, such as enjoying listening to Turkish music $(\mathrm{U}=7.053, \mathrm{p}<, 05)$, finding Turkish food delicious $(U=7.882, p<.001)$, the rich food $(U=7.994, \quad p<.01)$, finding Turkish architecture different $(U=7.111, p<05)$, rich artifacts and handicraft $(U=7.888, p<.01)$. NonMuslims, however, are significantly more likely than Muslims to believe that Turkey is expensive $(U=9.101, p<.01)$.

\section{Country of origin}

Participants came from 61 different countries, with some countries having just one representative (Australia, Bangladesh, Cambodia, Ethiopia, Finland, Germany, Iran, Kosovo, Libya, Moldova, Mongolia, Myanmar, Uzbekistan, Pakistan, Portugal, South Africa, Sudan). Indeed, there are only three countries which have more than 20 students: Bosnia and Herzegovina, $\mathrm{N}=22$, Russia, $\mathrm{N}=29$, Syria, $\mathrm{N}=23$

In the interests of working with a representative sample, only those three countries with numbers of more than 20 were further analyzed. None of the items achieved either a maximum agreement rating (median=5, 
strongly agree) or a minimum agreement rating (median $=1$, strongly disagree). Most of the items in all three well-represented countries were given a median of 4 , however since a median of 4 (agree) is actually the most frequent rating across all students, it is really the items arousing disagreement (median=2) that are of most interest. Even these mostly fall within the same range as those for students overall (Items 18, 20, 46).

\begin{tabular}{|c|c|c|}
\hline Open coding & Axial coding & Selective coding \\
\hline Shoes & Acceptable behavior & \\
\hline \multicolumn{3}{|l|}{ Marriage } \\
\hline Power relationships & Family & \\
\hline \multicolumn{3}{|l|}{ Gender roles } \\
\hline \multicolumn{3}{|l|}{ Tea } \\
\hline Baklava & Food and drink & \\
\hline \multicolumn{3}{|l|}{ Meat } \\
\hline \multicolumn{3}{|l|}{ Relationship to L1 } \\
\hline ELF & Language & \\
\hline \multicolumn{3}{|l|}{ Appearance } \\
\hline \multicolumn{3}{|l|}{ Ethnicity } \\
\hline Stereotypes & Culture snock & Impressions of Turkey I \\
\hline \multicolumn{3}{|l|}{ Prejudices } \\
\hline \multicolumn{3}{|l|}{ Literature } \\
\hline Dances & Culture & \\
\hline \multicolumn{3}{|l|}{ Music } \\
\hline \multicolumn{3}{|l|}{ Helpfulness } \\
\hline Hospitality & Turkish character & \\
\hline \multicolumn{3}{|l|}{ Talkative } \\
\hline Muslim/Christian & Religion & \\
\hline \multicolumn{3}{|l|}{ History } \\
\hline \multicolumn{3}{|l|}{ Nature } \\
\hline Minorities & Politics & \\
\hline
\end{tabular}

Examination of the twelve student interviewee reflections produced 23 general themes, progressively coded according to axial themes $(n=10)$ and a final over-arching theme, summed up as students' impressions of Turkey (see Table 1). The comments are quoted directly as they were written, including the occasional error, since this is more authentic than a corrected version might be.

\section{Acceptable behavior}

Regarding acceptable behavior, the Turkish custom of removing shoes before entering a dwelling was mentioned. In fact, this is the norm in many cultures, not just Turkey, as B. from Korea points out. In other words, she indicates that this behavior is not a problem since it is similar to the expectations of her own culture. 


\section{Family}

B. also points out to the strong gender discrimination in family roles, and she comments with interest on Turkish marriage customs, where "people attach money or gold to wedding dress!" P. from Turkmenistan makes a similar observation, saying "mostly women are altruistic, family, husband, children come first...men take care of their family [they are the] dominant figure".

\section{Food and drink}

According to A. from Moldova "tea is the 'soul' of this country, while, according to R. from Ethiopia, "the food is really good, especially baklava". One girl student, however, who did not give her name or her origin, says "It was very difficult to get used to food in Turkey when I first came. They like soup and vegetable foods. We don't make meals without meat".

\section{Language}

The Turkish language is mentioned by several of the interviewees in their reflections. According to S. from the Philippines, for instance, "Turkish is a magnificent language and it is very fun to learn". However, he notes, in an interesting observation, "since they are very much afflicted with their own language, Turkish people are having hard times learning a new language". Therefore, he concludes, "we must not forget that there are people whom we cannot communicate with just our own language, that's why English is a must too!" Another interesting comment is made by an anonymous boy student who says:

When I first came to Turkey I thought they were going to try to change me and assimilate me. For this reason, I put a barrier between learning Turkish and myself. But in time...I realized it was not harmful to my mother tongue.

\section{Culture and culture shock}

Several of the interviewees mention culture shock, often in relationship to "hardships with our appearances" against which there are "still stereotypes and prejudices" (K. from Kazakhstan). The anonymous girl student comments that "Turkish people are not used to black people. They look continually. Some people take our photos without our consent". B. from Korea, however, concludes that "even though their looks are extremely different" Korean and Turkish people are "like brothers".

As for culture, as L. from Tajikistan points out, the "literature and culture of a country is closely related to each other, because a literature describes the culture itself". A. from Moldova describes Turkish dances as 
"amazing", and "also Turkish people are very good singers. Singing is like breathing, as you can't live without air, they can't live without singing: it is their source of life".

\section{Turkish character}

Several interesting observations are made about Turkish character. According to B. from Korea "Turkish people love to help people", and she quotes an example of when a stranger helped her to find her homestay. Turkish hospitality is also mentioned by L. from Tajikistan, while, according to A. from Moldova "Turkish people love to talk, and to talk on different subjects, about politics, religion, work, daily life, problems, and especially about football".

\section{Religion}

Religious differences are mentioned by two of the interviewees, but, since they are both Muslim, religious beliefs do not seem to be a problem. As P. comments, there are many similarities between Turkey and Turkmenistan: "First of all, both of them [are] Muslim countries". And although, as R. explains, Ethiopia is a Christian country, her tribe is Muslim "so we are quite similar".

\section{Environment}

According to P. from Turkmenistan, "Turkey is very beautiful with the historical background". The historical and natural environment is also mentioned by R. from Ethiopia, who advises that Turkey "is an amazing place to visit".

\section{Political}

Not many of the interviewees were brave enough to venture into the political area. P. from Turkmenistan, however, refers to political problems in Turkey, especially in relation to different ethnic groups. As we can see, then, the 12 interviewees provided thoughtful reflections on their Turkish experience. This qualitative data added a useful and interesting extra dimension to the quantitative data obtained from the questionnaires.

\section{CONCLUSION}

Perhaps the main message of the study is that international students' views are generally positive. Where there are problems, perhaps the most serious ones seem to revolve around younger students (who tend to feel discriminated against), around non-Muslims (who tend to feel a lack of religious freedom), and around women (who feel a lack of freedom generally, especially religious freedom). These are important issues which 
Turkey might do well to address if it wishes to increase its international student population and to expand the variety of nationalities which are willing to come here. Especially concerning are the somewhat negative views of young people, women and non-Muslims. These people, after all, form a large potential market, so their dissatisfaction should not be overlooked by an education sector seeking expansion.

The problem might be tackled from two directions. Firstly, the target market might be better informed of conditions in Turkey, so that these things do not come as such a surprise when they get here; they might also be given advice on how to deal with these kinds of problems, and support when such problems are encountered. From the other direction, Turkish people should be better informed about the world outside, beginning from quite a young age. Turkey is known internationally for its monolingualism and monoculturalism, which may contribute to the kind of discrimination that younger people report feeling here. Turkey is also known for its strong religious beliefs, which may account for the lack of freedom felt by women, especially non-Muslim women. If an awareness of the outside world, including its geography and global cultures were begun from the time children go to school, it might help to develop a more outward-looking generation in which it would be easier for "yabanc1" to feel comfortable.

On an institutional level, such as universities, students' intercultural awareness can be developed by organizing orientation programs, courses, events, and activities inside the campus. Off campus activities can also be useful (Yan \& Sendall, 2016). Most, if not all, universities already have international students, a multi-cultural academic society in which the students try their best to adapt themselves to a new cultural context, which is quite different from their high school environment and local culture (Hyman, Vu \& Beiser, 2001). Banks and Banks (2003) point out that culturally rich and diverse educational environments may facilitate the integration and adaptation processes for international students. Formal education may also enhance students' understanding of intercultural competence (Hismanoglu, 2011; Moran, 2001). If universities are to attract more international students, they need to take into account the necessity of establishing the means to satisfy students of all ages, of both genders, holding differing beliefs, and from widely-varying cultures and national origins.

Social events and cultural celebrations at national and international levels such as Children's Day, Language and Culture Olympiads, Music, Folk and Touristic Festivals in different cities and so on can encourage cross-cultural understanding and develop positive feelings towards other cultures, people, and languages. In such festivals and events, people and students from different cultures and societies find the opportunity to appreciate the food, music, folklore and customs of the diverse cultures in a 
friendly atmosphere. If a picture is worth a thousand words, a direct experience and encounter with various cultures can be very meaningful, valuable and worthwhile from many aspects such as overcoming cultural bias.

As reported from previous research, international students encounter many challenges in a new culture because of language and cultural barriers, difference in educational systems, financial difficulties, social contact problems, racial discrimination, differing beliefs, alienation, and homesickness. Given the increasing numbers of students in Turkey, we might expect that some of them will also experience some of these problems. Overall, however, it would appear from the results of this study that international students are generally positive about what they encounter in Turkey. Although there are some negative points of view expressed, international students mostly report feeling comfortable with the culture, the environment, the food, the language and the people, and find people friendly and hospitable.

\section{REFERENCES}

Altbach, P. G. \& Teichler, U. (2001). Internationalization and exchanges in a globalized university. Journal of Studies in International Education, 5(1), 5-25. doi:10.1177/102831530151002

Andrade, M. S. (2006). International students in English-speaking universities: Adjustment factors. Journal of Research in International Education, 5(2), 131-154. doi:10.1177/1475240906065589

Archer, C. (1986). Culture bump and beyond. In Culture bound: Bridging the cultural gap in teaching. Joyce Merrill Valdez (Ed.) London: Cambridge University Press.

Banks, J. A. \& Banks, C. A. M. (2003). Multicultural education: Issue and perspectives (4th ed.) New York: John Wiley and Sons.

Baruch, Y., Budhwar, P.S. \& Khatri, N. (2007). Brain Drain: Inclination to Stay Abroad After Studies. Journal of World Business, 42(1), 99-112. doi:10.1016/j.jwb.2006.11.004

Bateman, B. (2002). Promoting openness toward culture learning: Ethnographic interviews for students of Spanish. Modern Language Journal, 86(3), 318331. doi:10.1111/15404781.00152

Biggs, J. (1999). Teaching international students: Teaching for quality learning at university. England: SRHE and Open University Press.

Byram, M. (1989). Cultural studies in foreign language education. Clevedon: Multilingual Matters.

Byram, M. \& Feng, A. W. (2005). Teaching and researching intercultural competence. In Handbook of Research in Second Language Teaching and Learning. E. Hinkel, (Ed.). 911-930. Mahwah, NJ: Lawrence Erlbaum.

Brown, H. D. (2007). Principles of language learning and teaching. White Plains, NY: Pearson, Longman.

Carr, J. L., Koyama, M. \& Thiagarajan, M. (2003). A woman's support group for 
Asian international students. Journal of American College Health, 52(3), 131-134. doi:10.1080/07448480309595735

Charles-Toussaint, G. C. \& Crowson, H. M. (2010). Prejudice against international students: the role of threat perceptions and authoritarian dispositions in U.S. students. The Journal of Psychology: Interdisciplinary and Applied, 144(5), 413-428. doi:10.1080/00223980.2010.496643

De Vaus, D. (1995). Surveys in Social Research. (4th ed.) London: Allen \& Unwin. Dustmann, C. \& Weiss, Y. (2007). Return migration: theory and empirical evidence from the UK. British Journal of Industrial Relations, 45(1), 23656. doi:10.1111/j.14678543.2007.00613.x

Fass-Holmes, B. \& Vaughn, A. (2015). Evidence that international undergraduates can succeed academically despite struggling with English. Journal of International Students, 5(3), 228-243.

Furnham, A. (1997). The experience of being an overseas student. In Overseas students in the higher education, edited by McNamara, D. and Harris, R. London: Routledge.

Gareis, E. (2012). Intercultural friendship: Effects of home and host region. Journal of International and Intercultural Communication, 5(4), 1-20. http://dx.doi.org/10.1080/17513057.2012.691525

Glass, C. R. (2012). Educational experienced associated with international students' learning, development, and positive perceptions of campus climate. Journal of Studies in International Education, 16(3), 226-249. http://dx.doi.org/10.1177/1028315311426783

Hammer, M. R., Bennett, M. J. \& Wiseman, R. (2003). The intercultural development inventory: a measure of intercultural sensitivity, International Journal of Intercultural Relations, 27(2003), 421-443.

Hanassab, S. (2006). Diversity, international students, and perceived discrimination: Implications for educators and counselors. Journal of Studies in International Education, 10(2), 157-172. http://dx.doi.org/10.1177/1028315305283051

Hart, R. (2012). Preparing for your move abroad: Relocating, settling in, and managing culture shock. London; New York: Kuperard and Random House Publishers.

Hismanoglu, M. (2011). An investigation of ELT students' intercultural communicative competence in relation to linguistic proficiency, overseas experience and formal instruction. International Journal of Intercultural Relations, 35(6), 805-817. doi:10.1016/j.ijintrel.2011.09.001

Hitlan, R. T., Carillo, K., Zárate, M. A. \& Aikman, S. N. (2007). Attitudes toward immigrant groups and the effects of the 9/11 terrorist attacks, Peace and Conflict: Journal of Peace Psychology, 13(2), 1-18. http://dx.doi.org/10.1080/10781910701270970

Hofstede, G. (1997). Cultures and organizations: Software of the mind. Intercultural cooperation and its importance for survival. New York: McGraw-Hill.

Hyman, I., Vu, N. \& Beiser, M. (2000). Post-migration stresses among Southeast Asian refugee youth in Canada: A research note. Journal of Comparative Family Studies, 3(2), 281-293.

Jung, E., Hecht, M. L. \& Wadsworth, B. C. (2007). The role of identity in 
international students' psychological well-being in the United States: A model of depression level, identity gaps, discrimination, and acculturation. International Journal of Intercultural Relations, 31(5), 605-624. http://dx.doi.org/10.1016/j.ijintrel.2007.04.001

Lee, J. \& Rice, C. (2007). Welcome to America? International student perceptions of discrimination. Higher Education, 53(3), 381-409. doi:10.1007/s10734005-4508-3

Locks, A. M., Hurtado, S., Bowman, N. A. \& Oseguera, L. (2008). Extending notions of campus climate and diversity to students' transition to college. The Review of Higher Education, 31(3),257-285.

McClure, J. W. (2007). International graduates' cross-cultural adjustment: Experiences, coping strategies, and suggested programmatic responses. Teaching in Higher Education, 12(2), 199-217. doi:10.1080/13562510701191976

Meeuwisse, M., Severiens, S. E. \& Born, M. P. (2010). Reasons for withdrawal from higher vocational education. A comparison of ethnic minority and majority non-completers. Studies in Higher Education, 35(1), 93-111. doi:10.1080/03075070902906780

Mesidor, J. \& Sly, K. (2016). Factors that contribute to the adjustment of international students. Journal of International Students, 6(1), 262-282.

Moran, P. R. (2001). Teaching culture: Perspectives in practice. Boston: Heinle \& Heinle.

Noh, S. \& Kaspar, V. (2003). Perceived discrimination and depression: Moderating effects of coping, acculturation, and ethnic support. American Journal of Public Health, 93(2), 232-238.

Oberg, K. (1960). Cultural shock: adjustment to new cultural environments. Practical Anthropology, 7, 177-182.

Özer, M. (2012). Türkiye'de uluslararası öğrenciler, Journal of Higher Education and Science, 2(1), 010-013. doi: 10.5961/jhes.2012.027

Palmer, Y. (2015). The not-so-easy road of overseas study: life like an outsider. Journal of International Students, 5(4), 541-544

Poyrazli, S., Kavanaugh, P. R., Baker, A. \& Al-Timimi, N. (2004). Social support and demographic correlates of acculturative stress in international students. Journal of College Counseling, 7(1), 73-82. doi:10.1002/j.216118822004.tb00261.x

Probertson, M., Line, M., Jones, S. \& Thomas, S. (2000). International students, learning environments and perceptions: a case study using the Delphi technique, Higher Education Research and Development, 19(1), 89-102. doi:10.1080/07294360050020499

Rienties, B., Beausaert, S., Grohnert, T., Niemantsverdriet, S. \& Kommers, P. (2012). Understanding academic performance of international students: the role of ethnicity, academic and social integration. Higher Education, 63(6), 685-700. doi:10.1007/s10734-011-9468-1

Russell, J., Rosenthal, D. \& Thomson, G. (2010). The international student experience: three styles of adaptation. Higher Education, 60(2), 235-49. doi:10.1007/s10734-009-9297-7

Saenz, V. B., Ngai, H. N. \& Hurtado, S. (2007). Factors influencing positive 
interactions across race for African American, Asian American, Latino, and White College students. Research in Higher Education, 48(1), 1-38. http://dx.doi.org/10.1007/s11162-006-9026-3

Sam, D. L. (2001). Satisfaction with life among international students: An exploratory study. Social Indicators Research, 53, 315-337. doi:10.1023/A:1007108614571

Sawir, E., Marginson, S., Deumert, A., Nyland, C. \& Ramia, G. (2008). Loneliness and international students: An Australian study. Journal of Studies in International Education, 12(2), 148-180. doi:10.1177/1028315307299699

Schumann, J. (1975). Affective factors and the problem of age in second language acquisition. Language Learning, 25(2), 209-235. doi:10.1111/j.14671770.1975.tb00242.x

Schumann, J. (1976). Second language acquisition: The pidginisation hypothesis. Language Learning, 26(2), 391-408. doi:10.1111/j.14671770.1976.tb00283.x

Scollon, R. \& Scollon, S. W. (1995). Intercultural communication. Oxford: Blackwell.

Severiens, S. \& Wolff, R. (2008). A comparison of ethnic minority and majority students: Social and academic integration, and quality of learning. Studies in Higher Education, 33(3), 253-266. http://dx.doi.org/10.1080/03075070802049194

Sherry, M., Thomas, P. \& Chui, W. H. (2009). International students: A vulnerable student population. Higher Education, 60(1), 33-46. doi:10.1007/s10734009-9284-Z

Singh, J. (2008). Poverty in South Asian region: A comparative study. ICFAI Journal of International Relations, 2(1), 60-73.

Spindler, G. D. (1987). Education and cultural process toward an anthropology of education. Prospect Heights, IL: Wave land Press.

Sümer, S., Poyrazli, S. \& Grahame, K. (2008). Predictors of depression and anxiety among international students. Journal of Counseling \& Development, 86(4), 429-437. doi:10.1002/j.1556-6678.2008.tb00531.x

Terui, S. (2012). Second language learners' coping strategy in conversations with native speakers. Journal of International Students, 2(2), 168-183.

Thomas, L. (2002). Student retention in higher education: The role of institutional habitus. Journal of Education Policy, 17(4), 423-442. http://dx.doi.org/10.1080/02680930210140257

Trice, A. G. (2004). Mixing it up: International graduate students' social interactions with American students. Journal of College Student Development, 45(6), 671-687. http://dx.doi.org/10.1353/csd.2004.0074

Wilcox, P., Winn, S. \& Fyvie-Gauld, M. (2005). It was nothing to do with the university, it was just the people: The role of social support in the first-year experience of higher education. Studies in Higher Education, 30(6), 707722. http://dx.doi.org/10.1080/03075070500340036

Yan, Z. \& Sendall, P. (2016). First year experience: how we can better assist first year international students in higher education. Journal of International Students, 6(1), 35-51

Yeh, C. J. \& Inose, M. (2003). International students' reported English fluency, 
social support satisfaction, and social connectedness as predictors of acculturative stress. Counselling Psychology Quarterly, 16(1), 15-28. doi:10.1080/0951507031000114058

Yoon, E. \& Portman, T. A. A. (2011). Critical issues of literature on counseling international students. Journal of Multicultural Counseling \& Development, 32(1), 33-44. doi: 10.1002/j.2161-1912.2004.tb00359.x

Zhou, C. \& Griffiths, C. (2011). Intercultural communicative competence. English Language and Literature Studies, 1(2), 113-122. http://dx.doi.org/10.5539/ells.v1n2p113

YAKUP ÇETIN, PhD, is an EFL instructor at Ishik University. His research focuses on the relationship between second language learning, media, and psychology. He has authored EFL coursebooks and developed course materials intended for second language learners. His comments have been published in popular Turkish newspapers. He has received several awards for his research from Fatih University Email: ycetin@hotmail.com

MUSTAFA BAHAR, PhD is an assistant professor of measurement and evaluation. He worked as teacher and test developer for twelve years, coauthoring several books. For the last seven years he has been teaching measurement and evaluation, foreign language testing, research methods and statistics for social sciences. He is also author of Assessment in Language Teaching (Turkish). His specific research interests focus on learner perceptions, high stakes testing and relationship between test and achievement. Email: dr.olcme@gmail.com

CAROL GRIFFITHS, PhD has been a teacher, manager and teacher trainer of ELT for many years, and has taught in many places around the world, including New Zeland, Indonesia, Japan, China, North Korea and UK. She currently works as Associate Professor in the ELT Department at MEF University in Istanbul. She has presented at numerous conferences and published widely. Learner issues, teacher education, and using literature to teach language are her major areas of research interest. Email: carolgriffith5@gmail.com. Website: www.carolgriffiths.net 